\title{
From Modern to Post-Modern: A Sociological Analysis of Genet's The Balcony
}

\author{
Neelam Mittal, Saumya Rawat \\ Department of English, Satyawati College, Delhi University, India \\ Department of English, Dayal Singh College, Delhi University, India
}

\begin{abstract}
Genet's The Balcony is a sociologically relevant play for contemporary society. The play depicts a world-view troubled by a proletariat revolution against the unjust, self-serving and irresponsible power structures like the judiciary, the defence system and religion. Common men get fascinated by these power structures and want to impersonate the roles of the Bishop, the Judge and the General in Madame Irma's studios. The revolution against these power structures is thwarted by the fascination of the masses for the power vested in these power positions. However, the chief of police and Irma form an alliance to overtake these slow and delinquent power structures and establish a more potent and more abiding power regime called the technocratic society. In this regime, things move fast and there is no time to waste. Simultaneously, there is a sense of sacrilege of values and splintering of meaning itself due to proliferation of images created by the photographers at the behest of the Chief-of-Police. However, the Chief-of-Police, intoxicated with his own power-position mistakes his ascesis as permanent and absolute. It is the court ambassador. The Envoy, who articulates his power positions as sure to be surpassed by another power-structure just as he superseded the traditional power-structures of the Bishop, the Judge and the General. The paper hence undermines the fortification of any one power structure or episteme as ultimate, absolute and final and presents a postmodernist view of inconclusivity, unfinalizability and indefinite recession of meaning.
\end{abstract}

Keywords: Carnivalesque, Performativity, the Post-Modern Quintessence, Reciprocity of Power Relationships, Technocratic society.

\section{Introduction}

The terms 'modern' and 'post-modern' demarcate a whole set of political, social and cultural ideas. Political scientists date the starting point of modernity back to the French Revolution. Art historians fix it close to the trends of impressionism and cubism - from the late nineteenth century up to the 1914. In literature writers like Joyce and Proust broke the dams of conventionalism accompanied by theorists like Bergson and Nietzsche, who displayed humanity's irrational and brutish side, exposing the human psyche as distorted and fragmented. Nietzsche declares that with the death of god modernism is heralded. Barthes declares that with the death of the author, post-modernism is ushered in. Saussure's modernist semiotics operates in the realm of binary opposites. Signification, though arbitrary, is determinable and determinate. Post-modernist Derrida discredits binary opposites, and cogitates that in the grand scheme of signification all signifieds are also signifiers, therefore each word exists in a complete web of denotations and connotations so that no one meaning can be said to be final, stable and invulnerable to reconsideration. Signification is unstable and indeterminate and so is meaning. The splurge of mass media added to informational fragmentation and semiotic dispersal. The constitution of reality gradually became a sequence of pictures - a patchwork staged by the mass media. The prevailing view among theorists like Baudrillard, Frederic Jameson, and Hal Foster is that post-modernism remains an art of pastiche and simulation that render history reified, fragmented, fabricated - both imploded and depleted. The present analysis explores how Genet's The Balcony displays a move from the modern to the post-modern sociological paradigm: a move from the modernist loss of values and decadence as in the figures of the Bishop, the Judge and the General to a post-modernist sense of recession of meaning and reality and the proliferation of images of a non-existent reality.

\section{The Traditional Power-Structures in the Play: an Embodiment of the Modernist Paradigm of the Hollow Men in Search of Identity.}

In consonance with his own socially, sexually and economically marginalized position, Genet always joined hands with the uprooted and the marginalized. The Balcony depicts a working class revolution against the power structures which oppress and exploit them. The momentousness of these power structures is fortified in Madam Irma's brothel through role- playing by common people. Laymen come to Mme Irma's brothel to don the roles of Bishop, Judge and General. These traditional symbols of power and authority, the bastions controlling 
people's morality, spirituality and the guardians of political and civil safety, are presented as incompetent and delinquent, without adequate power and efficacy. They are comparable with T.S.Eliot's "The Hollow Men":

We are the hollow men

We are the stuffed men

Leaning together

Headpiece filled with straw...( Eliot 30)

But, these figures still hold sway over the consciousness of the common man so that laymen come to Irma's Balcony to impersonate these roles and feel the power associated with them. Instead of catering to the libidinal desires of the customers, Madame Irma's brothel and her studios cater to the customer's desire for exercising power. It is a way of revolting against their actual position of powerlessness.

Their performances lead to crucial revelations to the players and further to the spectators/readers. Revelations like:

(a) In the fashion of Prospero-Caliban interdependence, reciprocity is central to the oppressor-oppressed relationship where the oppressor's power depends on the debasement and subservience of the oppressed and conversely the acknowledgement of the oppressor's power by the oppressed.

(b) Bishop's realization that he does not seek penitence but sin in the eyes of the sinner, so that his sublime function of spiritual upliftment turns into promoting evil.

(c) That the judge needs criminals to maintain his authoritative status to apportion laws to the common people.

(d) General, too, is engrossed in self-glorification. Mud and blood on his patent lather and oxblood boots are essential pre-requisites for his display of bravery. His errand in this battle seems to be an objective and impersonal one-- with no specified enemy or purpose. It can be any battle irrespective of the antagonist or the purpose of the battle. The irrationality and chaotic off-handedness of the battle is reminiscent of Stephen Spender's "Two Armies":

Once a boy hummed a popular marching song, Once a novice hand flapped the salute; The voice was choked the lifted hand fell, Shot through the wrist by those of his own side. [1] and the helter- skelter confused soldier, in Charlie Chaplin's film "The Great Dictator" (1940). A highly self-centered General, he is concerned only with the first person 'I' and 'my'. The common soldier's death is just a decorative detail to enhance the General's glorified image. The deplorable plight of the war situation has found emphatic expression in Brecht's Mother Courage and Her Children (1985), where Mother Courage remarks that victories are for those to celebrate who run the war machinery. In a war, the lot of the poor man is always disastrous: hunger, deprivation and strife. She remarks:

They're ruined, that's what. They are so hungry I've seen them digging up roots to eat. I could boil your leather belt and make their mouths water with it. (Brecht 14). [2]

Genet goes a step further and shows a General lost in his own hallucinations about victory and self-apotheosis. He's lost in images and reflections reflected ad infinitum:

...I want to be a General in solitude. Not even for myself, but for my image, my image for its image, and so on. (Genet 23) [3]

Performativity is important in Genet as a device enabling the spectator to read theatre as a text. There is a recession of the identity of the General. The General is interested in making an image; only the image remains. The real potency and efficacy of the General is lost. We witness an assertive and self-conscious theatricality in modern avant-garde theatre.

From the start we know that the playwright is not endeavouring to evoke a world of fiction whose significance and effectiveness depends on our ability to forget that we are sitting in a theatre watching a play. Instead, far from hiding the theatricality of his medium, he capitalizes upon it. Hence, performance in the first three scenes is subversive, although the subversion is inadvertent on the part of laymen. Irma remarks:

When it's over, their minds are clear. I can tell from their eyes. (Genet 31) And Carmen aptly says:

No sooner is it finished than it starts all over again... They would like it never to end. (Genet 31)

In spite of the players' new awareness about the delinquencies inherent in these socially prestigious roles, there's a deliberate and comfortable slinking back into obliviousness about these truths. The sense of hopelessness about positive change and tenacity for the established social order on the part of the masses comes to the fore. The salacious masses need to be directed by some agency. They are reminiscent of Phillip Sidney's reference to the "slave-born Muscovite [who] call it praise to suffer tyranny" (Sidney 47). [4]

The sado-masochistic nature of power relationships is explored in scene 4 in the play. If the oppressor finds fulfilment in a sadistic stance, the oppressed is no less complicit in this power relationship. A masochistic instinct takes over the oppressed who gets so inured to being whipped that he feels a vacancy without the oppressor. He needs some authority to direct, cajole and coerce him into doing things. It anticipates the need of 
the idea of Bishop, Judge and General, real or fake, for the commons. As we shall later discuss, this tendency of the masses will be the cause for the failure of the revolution.

\section{Brothel Operates Through The Interpellation Of The Human Subject.}

Irma: My house is a severe place...I don't allow any joking... [because] A smile means doubt. (Genet 26)

Irma, the Madame of the Brothel, the organizer of enterprise, operates in a realm where she has created her own power relationships, feeding into the fantasies of her customers, and simultaneously interpellating the minds of her prostitutes. It is necessary for her to stratify them into fixed subject positions where they feel convinced that they are happy and better off than the denizens of the real world. Those who try to extricate themselves from this oppression/conditioning are 'interpellated' [5] by the Ideological State Apparatuses in Louis Althusser's terms. When Carmen tries to imagine a 'real' house, where she does not have to play roles to feel a sense of potent identity, Irma suppresses Carmen's thoughts by throwing a new role at Carmen, that of Saint Theresa:

Irma: I really think you miss your apparition. Look, I can do something for you. I did promise it to Regina, but I offer it to you. If you want to, of course. Someone rang me up yesterday and asked for a Saint Theresa. (Genet 30)

At another point in the play, she suppresses Carmen's desire to meet her daughter by insisting on the impossibility of reaching the world outside:

Are you still set on going to see her? Don't be a fool. Between this place and the nursery in the country, there is fire and water, rebellion and bullets.

(Genet 27)

A point comes when Irma does not need to cajole Carmen to be devoted to her. Carmen herself says, "You know very well I'm devoted to you". She calls herself one of Irma's best whores who have performed extraordinarily well in playing myriad roles in the house of illusions. The brothel's descriptive denomination, the 'house of illusions', is very apt because Irma's house works by camouflaging reality. [Although, in the play this reality stares hard at the spectators through inadvertent revelatory exercise of subversive potency of performativity]

The two things which threaten illusions are a taboo in Irma's house. They are

\section{Affection/love}

No, I don't at all like the way they are looking at each other: it's too candid and straightforward. (she turns to Carmen). There you have the dangers of regularity.

It would be a catastrophe if my clients and girls smiled at each other affectionately. (Genet 36)

The setting of Irma's room is such that she can see what goes in her studios through a special apparatus. Madame Irma's panoptic gaze, as a means of control and surveillance, remains fixed on the proceedings in her studios. Irma's anxiety reminds of Foucault's exegesis in the second volume of History of Sexuality that subversive potential needs to be regulated by sublimating desire towards work. Foucault discusses how modern control of sexuality enables knowledge and control of the subjects. Modern control of sexuality parallels modern control of criminality, so that individuals internalize the norms laid for others' knowledge of individuals and also via individuals' knowledge of themselves. They become self-monitoring, self-scrutinizing and selfconforming subjects.

\section{Joke/carnivalesque}

Irma emphatically declares that her house is a severe place and that she does not allow any joking. Joking or carnivalesque in Bakhtinian terms has a 'subversive potency' [6]. In Rabelais and his World (1984), Mikhail Bakhtin, a Russian theorist, divides carnivalesque into three forms: ritual spectacles, comic verbal compositions and various genres of Billingsgate or abusive language. The carnivalesque mocked those in authority and parodied, and thereby, undermined the official ideas of society, history, destiny and truth as absolute and final. Irma's fear of jokes and the elements of the carnivalesque and maintenance of sombreness is an instinct for preservation of her own power and authority.

Hitherto, the analysis has anatomized a modernist worldview summed up in Yeats' lines 'things fall apart'. Genet's The Balcony, is definitely a modernist text exploring the experience of modernity: the technological and economic change, political shuffling, and the fractured subjective experience of the modern man. In sociological terms, the play begins at the transformative, wobbly, unstable stage of disintegration of traditional authoritative power structures, a stage where we operate in the arena of modernist tussle between the following dichotomies: the real (world outside) and the illusive (battening of fantasies and images in the grand Balcony), the authentic (the real power structures) and the inauthentic (role-players), earnest solemnity and carnivalesque flippancy. Lucien Goldmann's essay, "Genet's The Balcony: A Realist Play", discusses three 
stages in the development of the play. The first stage shows people who aspire for power and prestige and fulfil their dreams through role-playing in the house of illusions - the roles of Bishop, Judge and General - the traditional social roles which once exhibited power but now have only prestige in the minds of people without any real efficacy. The second stage shows "people who possess real power" (Goldmann, 127). But, they don't yet possess prestige associated with it. They are called by Goldmann as particular incarnations of what a sociologist would designate broadly as 'technocracy' (Goldmann 127). In the third stage, those who held power in the second stage acquire prestige as well in the minds of the masses. The traditional power holders, the Bishop, Judge and General lose efficacy in the modern world. And, why so? The play is written in the 1940s and translated into English in 1957, that is, post-world war scenario and a long way further from the industrial and technological revolution. In this scenario things move fast, unlike the slowness, inertness, pretentiousness and delinquency of the three traditional dignitaries. The exigencies of shortage of time and the need for quick action come to the fore when the chief-of-police assumes power:

Chief-of-police: I've no time to waste.

Irma: Allow me just a little more respite.

Envoy: A few seconds, for time is pressing...

Envoy: ....we're engaged in a race against the clock. It's we or they. Irma, think speedily. (Genet 60)

This sociological chronotope ( to use Bakhtin's term for spatio-temporal conjunction of a certain epistemological epoch ) is characterized by lack of time, need for swift concrete action, relevance of hard gritty facts and conversely non-feasibility of pretence (as in the General's case), spiritual claptrap (as in the Bishop's case) and emotional relationships. Very aptly, in tune with this epistemological credo, the two prospective love relationships envisaged in the play turn out to be abortive. Chantal is 'subtilized' into the symbol of rebellion and forced away from Roger, the leader of the revolutionaries. Irma and Chief-of Police love relationship remains one-sided with the Chief-of-Police more interested in power. That the Chief-of-Police holds power over Irma is evident from the manner in which he commands her:

Irma! Irma!...where is she? It is not her job to dress the wounds.

(Genet 84)

The Chief of police encompasses in his person a conglomerate of legal and military power. Irma is the procuress of industrial and technological advancements. She is the one who hands over a revolver to Arthur and she will procure the symbol of grand stature in "the form of a gigantic phallus, a prick of great stature". When the fake judge mentions the difficulty in procuring such a symbol, the Envoy replies: "Not so very. What with new techniques and our rubber industry, remarkable things can be worked out..."(Genet 70). In the technocratic age, the chief-of-police and Irma are going to work in conjunction. Chief-of-police can be understood in the image of a totalitarian ruler an absolute dictator whose power issues not from traditional power structures but from intimidation and coercion, who believes in quick action, and has Irma under him. Genet is picturing forth the advent of a technocratic society where two people will hold power. One, the organizer of enterprise: in the play Mme Irma, in sociological terms technologists and engineers. It would not be difficult to understand the importance of electronics, telecommunications, computers, and world wide websites in today's world. Without indulging in exaggeration we can say that it is the information technology industry and Bill Gates, CEO, Microsoft, who wield real power in this age of corporate globalization. Two, the Chief-of-Police who appropriates in his person political, military and legal power. The power of the state will be diminished

This mitigated power of the state is a replication or a fabrication of the former traditional power structure, duplicated through a photo-session of the fake Bishop, Judge, and General to bamboozle the masses by the Chief-of-Police for his smooth ascent to power position. Can we reposition and reconfigure the power equation in the technocratic age as follows: the so called 'first world', dictates military, political, and legal terms to the so called 'third world', a derogatory, denigrating denomination by the former. Further, the establishment of multi-national companies in countries like India, China and Philippines makes available cheap man-power in the form of the best intellectuals from IIT who become their life-long servants made to work for $24 \mathrm{x} 7$, turning this intellectual manpower into automatons not unlike Charlie-Chaplin's 1936 film Modern Times. The film is about the reification of the human subject. It shows how a factory worker turns into and automaton and mechanically continues the act of fitting nuts in bolts while on the way back home.

\section{Genet's Desire and yet Scepticism of a Successful Revolution}

In consonance with the increasingly post-modern climate of the play, Genet refrains from endorsing a progressive revolution. Genet's desire for and yet scepticism about successful revolutions is due to his recognition of strong pitfalls in the path of successful revolutions. In the play, the rebels 'subtilize' Chantal into the symbol of rebellion singing songs of a new life ahead. Resorting to such paraphernalia of revolution corrupts and trivializes its real aim. It is highly reminiscent of Brecht's Mother Courage where the eponymous character remarks that songs and the claptrap of patriotism is used to supplement and camouflage a lack in the war machinery. Hence, songs fill up the gaps and fissures at the core of the revolution. For the rebels, she is nothing 
but an assemblage of fiery eyes, nice voice, nice bosom, and propriety of manner. She reminds of Futura, the robot in Fritz Lang's film Metropolis. Interestingly, both Lang's Futura and Genet's Chantal are used as mechanical devices to lead a working class rebellion. Both are discarded after use. Futura is burnt at stake by the establishment; Chantal is killed by the rebels themselves. One of the central images used by modernists to fill the post-Nietzschian void was that of the machine. Post-modernism seems to have replaced the image of the simple machine with that of the hybrid of man and machine. Both Chantal and Futura are reminiscent of cyborgs: cybernetic organisms - half human, half computer. Like the 'cyborgs'[7] discussed in Donna Haraway's essay, "A Cyborg Manifesto: Science,Technology, and Socialist Formation in the late Twentieth Century", both Chantal and Futura are destroyed once their role is over because they prove a potent threat to those who created them.

\section{The Post-Modern Quintessence in the Play}

As Irma and the Chief-of-Police gain strength and power, the hitherto operational dichotomies between the real and the imaginary, the serious and the non-serious collapse. The Envoy becomes the point of articulation of the post-modern quintessence of breaking-up of language, logic and reason. Asked about the whereabouts of the queen, the Envoy says:

Her majesty, says the Envoy, is embroidering a handkerchief

Envoy: I mean that the queen is embroidering and that she is not embroidering....

Envoy: she is in a chest. She is sleeping. Wrapped in the folds of royalty, she is snoring.

... Chief of Police: Is the queen dead.

Envoy: she is snoring and she is not snoring...The queen is standing on one foot in the middle of the room and she...(Genet 56)

Envoy represents the post-modern quintessence in the play. He is a court ambassador. As expected, his is a twisted, circumlocutory, roundabout manner of conversation. But there is something more to it: there is a definite splintering of logic and reason in his speeches. At times, he simply seems to be indulging and reveling in language games, pointing to the postmodern rejection of the tragic and pessimistic conclusion that if one can not prevent Rome from burning, one might as well enjoy the fiddling that is left open to one. Queen becomes elusive, absent, unreachable and unknowable. This highlights the relation of simulation with power. Irma is made queen. Image masks the absence of a basic reality.

When media persons make Bishop, Judge and General pose for the required images of the three dignitaries, we are reminded of Jean Baudrillard's discussion of how a culture of detached media images has come to suffocate and out-clone the 'real world':

The Bishop: please do your job quickly, and in silence, the other rather stern. First photographer: we'll do our job, don't worry. (To the Bishop:) Get set for prayer, because the world ought to be bombarded with the picture of a pious man.

The Bishop (without moving): In fervent meditation.

First photographer: right, fervent. Get set.

The Bishop(ill at ease): but...how?

First photographer: Don't you know how to compose yourself for prayer? Okay, facing both God and camera. Hands together. Head up. Eyes down. That's the classical pose. A return to order, a return to classicism. (Genet 65-66 )

In scene 9, the stage has reached in the post-modern paradigm when the old-fashioned worries about the relationship of image and the world have become futile. The simulacra that Baudrillard refers to are the significations and symbolism of culture and media that construct perceived reality, the acquired understanding by which our lives and shared existence is rendered legible. Baudrillard calls this phenomenon the "precession of simulacra" [8]. The absence, unreachability and unknowability of the queen, Irma's becoming queen, and the ascent of the fake Bishop, Judge and General in the consciousness of the common people explain how an image masks the absence of a basic reality. Power, in the post-modern world, produces signs of its own resemblance.

The Chief-of-police is seen as unconsciously treading over the edge of the knife when he imagines his apotheosis in the glorified image consecrated in a tomb, erected for the sublimation and veneration of the chiefof-police as absolute and final. He misses the Envoy's point:

He who gets it will be there- dead- for eternity... From a secret point of the same room will run a road that will lead, after many and many a complication to another room where mirrors will reflect to infinity... the image of a dead man. (Genet 62)

The Envoy does not mention who will get it, or does he mean that many people will succeed this consecration one after the other. Mirrors will reflect to infinity the image of the dead man so that which reflection is real or that each is equally legitimate becomes a crucial question. 


\section{Conclusion}

The play ends with Irma's speech on a note of self-reflexivity and open-ended inconclusivity:

It took so much light...two pounds worth of electricity a day! Thirty-eight studios...in a little while I have to start all over again...distribute roles again, assume my own...you must now go home, where everything - you can be quite sure - will be falser than here...you will leave by the right, through the alley...(she extinguishes the last light.) it's morning already.( a burst of machine gun fire.) (Genet 86)

The play with its open-endedness emphasises an inconclusive nature of life, the best known formulation of which occurs in Bakhtin's Problems:

Nothing conclusive has yet taken place in the world; the ultimate word of the world and about the world has not yet been spoken, the world is open and free, everything is still in the future and will always be in the future. (Bakhtin166)

[1]. Spender, Stephen. Collection of Poems.

\section{References}

[2]. Brecht, Bertolt. Mother Courage and her Children.Oxford: Delhi.

[3]. Genet, Jean. The Balcony. Worldview: Delhi, 2001.

[4]. Sidney, Phillip. Astrophel and Stella. Worldview: Delhi,2002. Foucault, Michel. The History of Sexuality. Vol 11. The Use of Pleasure. Penguin:London,1992.

[5]. Althusser, Louis. Lenin and Philosophy and other essays. Monthly Review Press: New York, 1972

[6]. Bakhtin,Mikhail. Problems of Dostoevsky's poetics. ,19293.Haraway, Donna. “ A Cyborg Manifesto: Science,Technology, and Socialist Formation in the late Twentieth Century". Simians, Cyborgs and Women: The Reinvention of Nature. Routledge: New York, 1991.

[7]. Haraway, Donna. “ A Cyborg Manifesto: Science,Technology, and Socialist Formation in the late Twentieth Century”. Simians, Cyborgs and Women: The Reinvention of Nature. Routledge: New York, 1991.

[8]. Baudrillard, Jean. Simulacra and Simulation. Trans. Shiela Faria Glaser. Michigan press: Michigan, 1998 